NBER WORKING PAPER SERIES

EXPLAINING PENSION DYNAMICS

Rebecca A. Luzadis

Olivia S. Mitchell

Working Paper No. 3084

\author{
NATIONAL BUREAU OF ECONOMIC RESEARCH \\ 1050 Massachusetts Avenue \\ Cambridge, MA 02138 \\ August 1989
}

This research was funded under Grant No. 10-P-98289, Section 702 of the Social Security Act. Excellent computer programming was provided by Vivian Fields, and capable research assistantship by Angela Mikalauskas, Ed Montemayor, Amy Myers, and Silvana Possenbon. This paper is part of NBER's research program in Labor Studies. Any opinions expressed are those of the author not those of the National Bureau of Economic Research. 
NBER Working Paper \#3084

August 1989

\section{EXPLAINING PENSION DYNAMICS}

\section{ABSTRACT}

Some contend the US labor market will fail to adapt smoothly to an aging workforce, whereas others argue that employee pensions can and will play an important role in helping companies induce desired tumover patterns. This paper undertakes a longitudinal examination of pension retirement incentives in several dozen plans observed between about 1960 to 1980 .

The plans under study instituted many changes over this period, several of which enhanced the financial payoff to early retirement. These alterations included increases in benefit levels, reductions in early, normal and mandatory retirement ages, and cuts in the age at which pension present values peak (with retirement after that age penalized). We also find that simple indicators of pension plans' structural features (e.g. the plan's early retirement age) do not adequately summarize the complex financial incentives inherent in pensions, so that most of our attention is directed to analysis of financial benefit level measures.

Three major explanations for observed pension outcomes are evaluated empirically. Of special policy interest is an evaluation of pension responses to changes in Social Security benefit rules. Additionally, key differences in behavior are discovered between single employer and multi. employer pension plans. We conclude that pension plan behavior is systematically related to both labor and product market characteristics, and is responsive to retirement income policy.

Rebecca A. Luzadis

Department of Management

Miani University

Oxford, OH 45056

(513) $529-4215$
Olivia S. Mitchell

Dept. of Labor Economics

ILR-Corne11 University

Ithaca, NY 14853

(607) $255-2743$

and

NBER

1050 Massachusetts Avenue

Cambridge, MA 02138 
Though the full impact of labor force aging has not yet been felt in US labor markets, there is already widespread controversy regarding its likely effects. Some forecasters predict with alarm that the labor market will fail to adapt smoothly to an aging populace, creating severe and longlasting labor market shortages; other analysts contend that market forces will come into play making older workers more valuable and easing shorages. 1 Whether and how the labor market adapts to changes in the workforce age distribution depends on how able companies are to induce desired turnover patterns among older and younger employees. In this regard, the form and function of pension plans will play a key role in inducing people to remain on their jobs, or perhaps even more importantly to leave, at later ages.

Analysis of pension plan retirement incentives has been a growth industry in the labor economics profession over the last decade, though surprisingly few studies investigate the dynamic behavior of this extremely important labor market institution. Many researchers assume pension plans are static, probably because there are no nationally representative time-series panels on pension plans. 2 The present paper remedies this gap by documenting changes over time in pension retirement incentives using a large set of collectively bargained pension plans between 1960 and 1980. Analysis of these pension plans' retirement incentives reveals how they changed over time, and some possible explanations for why these changes occurred. We evaluate empirically three reasons for observed changes in behavior. Our goal is to determine whether and how pension plans can be said to respond to labor and product market conditions, as well as regulatory policy.

\section{Understanding Pension Retirement Incentives}

\section{The Target Retirement Age}

Understanding retirement benefit structures embedded in pension plans and why they change from time to time is made easier with the concept of a target retirement age. In particular, it

\footnotetext{
${ }^{1}$ Levine and Mitchell (1988).

${ }^{2}$ Mitchell and Luzadis (1988) review several studies which make this assumption.
} 
is known that private pensions are not generally actuarially neutral; rather, one important function of pension plans is to structure benefits so as to induce workers to leave the firm at a time consistent with the sponsoring firm's preferences. 3 Specifically, the firm is posited to have a target retirement date $\mathrm{R}^{*}$, when the value of compensation paid to workers equals the value of the workers' productivity at that firm. In a multi-period context with pensions, the employee's cumulated compensation value is the sum of his discounted wage strearn until retirement (PDVE(R)), plus the discounted pension benefit from retirement to death (PDVP(R)): $P D V E(R)+$ PDVP(R). Cumulative total compensation paid must not exceed the value of the worker's lifetime productivity (VMP(R)) for a competitive firm. Hence at the firm's target retirement date $\mathrm{R}^{*}$, lifetime productivity must be at least as great as cumulative total compensation including the pension discounted value (Lazear, 1979):

$$
\operatorname{VMP}\left(\mathrm{R}^{*}\right) \geq \operatorname{PDVE}\left(\mathrm{R}^{*}\right)+\operatorname{PDVP}\left(\mathrm{R}^{*}\right) \text {. }
$$

This structural implicit function formulation makes clear that the firm's target retirement date $\mathrm{R}^{*}$ depends on factors affecting employee compensation and pension profiles.

Turning from the firm to the worker's viewpoint, we posit that workers select their desired retirement dates by maximizing remaining lifetime utility, as a function of consumption $(C)$ and retirement leisure $(L), U=U(C, L)$, subject to time and money constraints. 4 The time constraint recognizes the finiteness of the worker's expected remaining lifetime; the money constraint is determined by labor market eamings for as long as employment continues, and by pensions and Social Security after retirement:

$$
\operatorname{PDVY}(\mathrm{R} \dagger)=\operatorname{PDVE}(\mathrm{R} \dagger)+\operatorname{PDVP}(\mathrm{R} \dagger)+\operatorname{PDVS}(\mathrm{R} \dagger) .
$$

As before, PDVE is the present discounted value of earnings but now is defined up to the worker's desired retirement date (Rt); PDVP is the expected present value of the pension annuity (given $R+$ )

\footnotetext{
${ }^{3}$ Several previous studies have found conclusive evidence that non-neutral benefit formulas have been found to strongly influence older workers' retirement decisions: see Burkhauser (1979); Fields and Mitchell (1984); Gustman \& Steinmeier (1989), and Stock and Wise (1988).
}

${ }^{4}$ See Burkhauser (1979) and Fields and Mitchell (1984). 
and PDVS is the expected present value of the Social Security annuity from R $\dagger$ to death. Here too, the retirement equation is an implicit function in $\mathrm{R} \dagger$ where the worker's target retirement date depends on factors reflecting preferences for work and income versus retirement leisure.

In equilibrium, firms design eamings and pension benefit profiles so as to ensure that workers' target retirement dates coincide with their own. To the extent that older workers' productivities vary across firms and workers differ in their tastes for income and leisure, the jointly preferred target retirement ages will vary in the cross-section. 5 As long as nothing else changes, employees select job and associated compensation profile/retirement dates consistent with their preferences, and neither employees nor employers have an incentive to alter the status quo. However an exogenous shift in any of the underlying variables may induce workers to reevaluate their target retirement dates and perhaps to alter their preferred retirement point. Thus, for instance, unexpected increases in Social Security retirement benefits would tend to induce unexpectedly (and to the company, undesirably) earlier retirement. Pension plans provide one means to offset unexpected behavioral changes with greater incentives to work longer 6

\section{Previous Evidence and Hypotheses}

Existing empirical pension studies suggest that company-sponsored pension plans do appear to be fairly dynamic, having altered their retirement incentives at several points over the years. However, there are as yet no clear-cut explanations for why they do behave this way. For instance, Lazear (1983) analyzed pension benefit changes over the period 1975-1980 in a small Banker's Trust survey, and found that some defined benefit (DB) pension plans (those that determined benefits primarily on service) increased their early retirement incentives over the fiveyear span. He hypothesized that the observed pension benefit changes were atributable to the

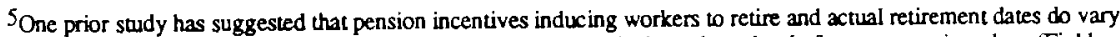
across firms and employees in the cross-section though that analysis evaluated only fourteen pension plans (Fields and Mitchell, 1984).

${ }^{6}$ In a fully flexible world some firms might be expected to readjust their wage profiles instead, but current law makes wage adjustments for older workers difficult if not impossible. In this event, firms will seek to alter primarily their pension offerings.
} 
raising of the legal mandatory retirement age in 1978, though no formal testing of this hypothesis was undertaken. A second study, by Bell and Barclay (1987), investigated a handful of large pensions surveyed by the US Bureau of Labor Statistics between 1974 and 1983, and again concluded that the payoffs to early retirement were increased substantially during this period. (No rationales were given.) Most recently, Mitchell and Luzadis (1988) evaluated pension changes over a much longer period 1960-1980 than any of the previously mentioned analyses, but could do so for only fourteen pension plans. Here too, they reported marked increases in pension benefit early retirement incentives over time. ${ }^{7}$ Like in Lazear's study, pensions that required mandatory retirement in the 1970's seemed to be most likely to enhance their early-out benefits by 1980 , though small sample conclusions were only suggestive.

Building on previous literature, we propose to examine here three general explanations for changes in pensions over time: the buy-out hypothesis, the response to regulation hypothesis, and the monitoring hypothesis. Each is considered in turn.

First, the "buy-out" hypothesis. This theory holds that pension plans began to induce earlier retirement in the US in response to declines in the relative value of employing older workers. One factor which undoubtedly altered the terms of trade across age groups in the last two decades was the large size of the "baby-boom" cohort. Indeed as Russell (1982) and others have shown, when this group entered the labor market, it depressed young workers' relative earnings as compared to those of older workers. Some companies doubtless used their pension plans to enhance early retirement's appeal, permitting them to substitute low-wage younger workers in place of more expensive older employees. 8 If pension plans did perform this buy-out function, it would be expected that enhanced early-out pension incentives would become most prevalent for

\footnotetext{
${ }^{7}$ Differences by plan type did show up; nonunion plans appeared to reward deferred retirement in all periods. ${ }^{8}$ Evidence on substitution between workers of different ages is offered by Levine and Mitchell (1988).
} 
most expensive, longest-tenured employees. ${ }^{9}$

This labor market rationale for the buy-out hypothesis should be complemented with a product-market explanation which recognizes sector-specific shifts in profitability over the last two decades. At least some firms seeking to downsize but finding themselves unable to adjust older workers' wage profiles were able to alter pension benefits over time (Mutschler and Schulz, 1987). Hence the product-market aspect of the buy-out hypothesis postulates that a trend toward early retirement in pension incentives was probably most evident in declining industries. Both aspects of the buy-out theory are examined empirically below.

A second, but not mutually exclusive, explanation for changes in pensions over time is termed the "response to regulation" hypothesis. By this we mean that early retrement pension incentives were probably altered in response to myriad changes in the pension regulatory environment between 1960 and 1980. One important legal change pertained to the raising of mandatory retirement ages: in the mid-1960's, Congress outlawed mandatory retirement earlier than age 65 , and then in 1978 raised the age to 70.10 Prior evidence suggests that there may be something to this hypothesis: earlier research on only 14 pension plans suggested that plans who required mandatory retirement during the 1970's were also those who enhanced their early retirement benefits by 1980 when the government circumscribed the practice (Mitchell and Luzadis, 1988). Another change in the legal environment came with a series of regulations governing both form and function of private pension plans, beginning with the Employee Retirement Income Security Act (ERISA) in 1974 (Clark, Gohmann and McDermed, 1988). Yet a third important set of regulatory changes affecting the pension environment had to do with frequent revisions in Social Security rules which made earlier retirement much more attractive over time. Benefit entitlement

\footnotetext{
${ }^{9}$ An evaluation of this hypothesis with a small sample (14 pension plans) shows that early retirement incentives are greatest among long-seniority employees, a finding consistent with the hypothesis that firms seck to buy out these workers using generous early pensions (Mitchell and Luzadis, 1988). However that study did not examine whether these differential pension rewards differed grealy before and after 1970, as would be expecied if the maturing of the baby boom drove down the cost of employing young workers.

${ }^{10}$ Mandatory retirement has since been eliminated for most jobs in the private sector.
} 
levels and incentives for retiring early rose significantly, 11 and at least some firms may have opted to offset Social Security early retirement enhancements by altering pension benefit formulas in the opposite direction over the years. Below we develop several tests of the "response to regulation" hypothesis.

A final explanation for pension changes in the last decades is termed here the "monitoring" hypothesis. This notion recognizes that firms use the retirement incentives of pension plans to encourage workers to leave when there are difficulties monitoring employee output directly (Hutchens, 1986). If monitoring costs rose between 1960 and 1980, which they may well have as company size grew, pensions may have served as a useful substitute for monitoring technology -perhaps especially in firms with few supervisors. As a consequence, the empirical analysis evaiuates whether pension retirement incentives appear to be related to the best available measures of monitoring costs, namely firm size and worker/supervisory ratios.

\section{Empirical Methods}

\section{Sample of Pension Plans:}

The eighty-three pension plans used in empirical analysis are defined benefit collectively bargained pension plans surveyed at several different points in time by the US Bureau of Labor Statistics (See Appendix D). Using published pension descriptions, we produced computer algorithms projecting pension eligibility and benefit amounts for sixty illustrative workers in each plan, assuming each reached age 60 in 1960,1970, and 1980.12 Benefits available for immediate retirement (age 60 was the earliest date for which retrement benefits were computed) were assumed to be determined by rules in effect as of that date; computations for retirement delayed beyond age 60 built in worker expectations regarding how the pension plan in question might have

\footnotetext{
11 For example in 1970 Social Security rules were actuarially more than fair for those deferring retirement, whereas by the 1980's workers postponing retirement beyond age 65 received lower discounted benelits than if they retired earlier (Fields and Mitchell 1984; Ippolito, 1988).

12 Of the 83 plans for which information is available, $39 \%$ are multiemployer and $61 \%$ are single employer plans; $42 \%$ are in durable manufacturing, $24 \%$ are in nondurable manufacturing, $16 \%$ are in transportation, communications and utilities, $10 \%$ are in services, and $8 \%$ are in construction and mining.
} 
increased benefits over time (both pre- and post-retirement). Specifically, the results reported here assume that pension benefits during this period were not indexed to the cost of living. 13 As a final step all annual pension benefit amounts were converted to present values relevant to each retirement age using a $2 \%$ real discount rate as well as mortality probabilities based on life tables specific to workers reaching age 60 in each of the three decades. 14

\section{Procedures}

A linear multivariate regression framework is used to explore the relationship between pension outcomes and the set of dependent variables of most interest. Explanatory terms in the reduced form multivariate analysis reflect the three hypotheses discussed above.

\section{Dependent Variables:}

There are several ways to parameterize a pension plan's retirement incentives. Our empirical approach analyzes key variables describing the pension values and provisions $(\mathbf{P})$. Some prior empirical studies examine indicators of pension plan structures such as the early or normal retirement ages, though our preferred approach is to analyze dollar benefit levels and increments as retirement is postponed. 15 Following in this tradition two sets of dependent variables are of initial interest:

(1) Pension provision variables, including indicators of the ease which which workers can retire early or late compared to the normal retirement age; and

\footnotetext{
${ }^{13}$ The BLS data source offers no direct insight on post-retirement increases these pension plans may have granted, so we are required to make an educated assumption about them in order to value benefit streams. Two altemative inflation adjusuments on pension benefits were explored: in the first case, benefits were assumed to be constant in nominal terms, and in the second case nominal benefits were assumed to be fully adjusted for inflation. Reality lies somewhere between these alternatives, though probably closer to the non-indexed case for the majority of pension plans in this study; sec Allen, Clark, and Sumner, 1986; and Kotlikoff and Smith, 1983). All results reported below use the no-inflation adjusument assumpcions. While the inflation assumption used does affect computed pension benefit amounts, it does not affect qual itative conclusions.
}

${ }^{14}$ See Appendix II for data creation information.

${ }^{15} \mathrm{Gusman}$ and Steinmeier (1989) analyze a similar though distinct set of pension variables and pension indicators for a sample of pension plans in 1983 and come to similar conclusions. 
(2) Pension value variables, including expected present values of pension benefit levels, rewards for deferring retirement, and the age at which pension present values peak.

Two general approaches are taken: the first focuses on "pension provision" variables, or key structural features of pensions thought to influence whether a worker chooses to retire early, normal, or late. Eight specific provisions may be investigated in this dataset, including each pension plan's early retirement age (ERETAGE); the years of service required to qualify for early retire ment (ESV); whether a supplement is added to early retirees' benefits (ESUPP); the normal retirement age (NRETAGE); the years of service required to qualify for normal retirement (NSV); whether the plan had a mandatory retirement policy (MR); and the plan's mandatory retirement age (MRAGE). In addition we include whether service is credited after the worker attains normal retirement age (SCANRA). Each of these structural pension provisions is used as a dependent variable in empirical analysis.

A second set of dependent variables uses what we believe to be more economically meaningful "pension value" variables. These are measures which directly attest to a pension plan's built-in financial incentives for and penalties associated with retiring early, normal, or late. Five dependent variables are the subject of special attention in this analysis, each of which is measured for workers contemplating retirement in 1960,1970 or 1980. The first, PKPENAGE, indicates the age at which a worker's pension present value stream peaked under the rules in effect for a given year. The second (third) dependent variable, PDVP62 (PDVP65), reflects each worker's present value of pension benefits if he were to retire at age $62(65)$. Finally we examine the slope of the pension present value hill between two different ages, indicating the incentives to delay retirement. These two variables we call PSLOPE65-62 and PSLOPE67-65, referring to the pension slope between age 65 and 62, or 67 and 65, respectively. Previous work suggests that variables constructed in this fashion are useful measures of the incentives to retire early versus late (Fields and Mitchell, 1984). 


\section{Explanatory Variables:}

Above we note that target retirement dates differ from one pension plan to another for various reasons, including differences in product market and labor market conditions faced by the sponsoring employer(s). In order to test the buy-out hypothesis more directly we postulate that firms in declining or unprofitable businesses will structure their pensions so as to reduce the target retirement date. Our empirical model therefore incorporates a profitability variable ROI5, which measures average return on investment in the industry over a five-year period preceding the year in question (e.g. the 1955-60 2-digit industry average is used for a pension plan observed in 1960). For the same reason differences in firm growth are captured, using the change in employment over five years preceding the year in question, EMPGWTHS. In general, profitable and growing industries are expected to encourage rather than discourage continued work at older ages. Hence, pension levels are anticipated to be lower and pension slopes higher in these cases.

We next focus on employee variables needed to test the buy-out hypothesis. First, other things equal, the hypothesis suggests that firms would wish higher-paid employees to retire earlier, ceteris paribus, with the same holding true for workers with more years of service (particularly since service is often explicitly rewarded in pension benefit formulas). For this reason, eamings and tenure variables are used to assess how pensions reward salient differences across workers. These are YRSERV, the amount of job tenure attained by each worker at age 60 and HIPAY, indicating whether the eamings profile was above average or at the maximum taxable wage level. Both would be expected to be related to higher pension benefit levels as well as lower work incentives under this view.

Testing the third hypothesis, the response to regulation notion, is more problematic because of the difficulty of constructing regulation variables. We can compute anticipated Social Security benefits for each worker should he decide to leave employment at various ages, which we believe captures Social Security's exogenous effects on the retirement incentives confronting workers in each decade. Previous research shows that Social Security benefit rules may be usefully summarized by indicators reflecting the (expected present value of the) level of Social Security 
benefits for an early retiree, and the change in benefits if a worker defers retirement (Fields and Mitchell, 1984). Specifically, two pairs of Social Security benefit variables are examined for each of the years of the data: PDVSS62 with SSLOPE65-62, and PDVSS65 with SSLOPE67-65. The first pair measures the present value of Social Security benefits a worker is entitled to if he retired at age 62 (PDVSS62), and second the slope of the Social Security benefit hill (in present value terms) indicating monetary value of delaying retirement between the ages of 62 and 65 (SSLOPE65-62). The second pair of variables focuses on similar variables for ages 67 and 65 respectively. As a final control we include two time effect dummy variables, to ascertain whether the 1960 's, an era of relatively little governmental reform and pension regulation, differed substantively from that of the [970's. It is recognized that the dime dummies cannot prove conclusively whether regulatory changes had an impact, but they should be suggestive about the hypothesis.

A final factor controlled on in the model is differences in firms' workforce monitoring capabilities. When productivity is difficult to monitor, as in large firms, the companies might lower retirement dates, other things equal, to avoid possible negative consequences of declining productivity with age. Such cross-firm and over time monitoring differences are controlled using firm size (FSIZE) and the proportion of production to total workers (PRODTOT). In general, we anticipate that where firm size or the proportion of production workers is larger, monitoring workers' productivity is more difficult which should tend to lower the age at which the pension plan offered peak financial rewards, and decrease pension rewards for delayed retirement.

\section{Results}

\section{Descriptive Statistics}

Table I reports mean values of key structural pension features including early, normal, and mandatory retirement ages in the Pension Digest plans as well as service requirements and other plan provisions. 16 The top panel of the table reveals that both the average early retirement age and

\footnotetext{
16 Mean values of explanatory variables over time are in Appendix III.
} 
the service requirement for early retirement dropped by roughly a full year between 1960 and 1980 , and in addition the prevalence of monetary supplements to induce early retirement rose over time. The bottom panel presents marginal increments to (discounted) pension benefits a worker would receive if he were to delay retirement from age 62 to 65 (PSLOPE65-62). Here the numbers show that the additional income gained by deferring retrement fell substantially over time. The age at which pension discounted values attained a maximum (PKPAGE) declined by more than a full year over this time. On all these counts, then, pension incentives for early retirement rose over time in our empirical sample. These findings agree with those presented earlier.

The plans in our sample altered their inducements to retire at the normal age or beyond, much less. This is evident from noting that during the 1960-1980 time period, the normal retirement age dropped by merely half a year. Other changes generally enhanced the incentives for retiring earlier but the directions are not unambiguous. The average age of mandatory retirement dropped by half a year while at the same time mandatory retirement become more prevalent. Marginal gains to deferring retirement beyond age 65 (PSLOPE67-65) became substantially more negative over the time period examined. All of these seem to increase the payoffs to retiring earlier rather than later. The picture is not completely clearcut, however, since between 1960 to 1970 plans began to require more service for normal retirement, and were more willing to credit service beyond the normal retirement age. Both of these changes created (other things equal) an incentive for workers to delay retirement. On the other hand the upward trend in service requirements was reversed by 1980.

In sum, while changes in the sample means over the years do not tell an entirely consistent story, the overall trend was toward greater rewards for earlier retirement.

Table 2 displays correlation coefficients among both the pension provision and the pension value variables. Most importantly, we highlight the very small degree of correlation between pension provisions and both benefit levels and retirement incentive terms. This proves that indicators of pension provision structures, such as whether a plan had a mandatory retirement provision or an early retirement supplement, are very imperfect substitutes for measures of plans' 
actual financial incentives to retire. For this reason the multivariate analysis reported below focuses only on the more economically interesting pension outcome terms, the pension value variables.

\section{Regression Results: Full Sample}

Table 3 displays estimated regression coefficients for five different dependent variables. The buy-out hypothesis implies that furms in industries experiencing profitability and growth would be those offering lower levels of pension benefits and greater rewards for continued work, while companies in declining industries might use their pensions to reduce the fraction of older more expensive workers. This surmise is partly corroborated as can be seen from an examination of coefficients on ROI5 and EMPGWTH. Lower benefit levels, conducive to continued work and delayed retirement, are found for both profitable and growing firms, consistent with predictions. Also consistent with the theory is the finding that the peak pension age is later in the more prosperous industries, as is the tendency to reward work after age 65 . Thus seven out of ten coefficients indicate that pensions are more likely to discourage continued work in depressed sectors, supporting the buy-out hypothesis. On the other hand, contrary to predictions, more prosperous firms also tend to offer less of a payoff for deferred retirement between ages 62 and 65.

The buy-out hypothesis also implies that some employers might use pensions to encourage early retirement of more expensive longer tenured employees. Evidence here is also strong as can be seen from the coefficients on HIPAY and EMPGWTH, though again not uniformly supportive. Statistically significant coefficients show that firms provide higher benefit levels to higher-paid and more senior workers, as is expected. In addition, workers with longer service are confronted with lower (or negative) payoffs to deferring retirement from age 62 to 65 , as well as beyond age 65 . Indeed high tenure workers face a lower peak pension age overall. Nevertheless, there is a bit of evidence on the other side: high wage workers appear to have higher peak pension ages and are offered higher gains to working up to age 65 (though not thereafter). Overall, however, the view receives strong support inasmuch as eight of ten coefficients are supportive of the hypothesis. 
Evidence on the response to regulation hypothesis is best categorized under two headings: Social Security effects, and other effects. Most of the Social Security variables have statistically imporant impacts on pension value variables at conventional significance levels, implying a strong association between retirement incendives in private pensions and the incentives embedded in Social Security benefit structures.

Despite the strength of the pension/Social Security links, the evidence provides only mixed support for the regulation hypothesis. Peak pension ages do rise with Social Security benefit levels (PDVSS62 and 65) as expected: this is consistent with the view that employers try to offset rising Social Security benefits by increasing company pension incentives to delay retirement. A similar pattern emerges for the slope variables (SSLOPE65-62 and 67-65): that is, a reduction in Social Security incentives to defer retirement is associated with an increase in peak pension ages. Less consistent with the hypothesis are other Social Security coefficient estimates. For instance there is no statistically significant relationship between early pension rewards and Social Security variables, and the Social Security coefficients in the post-65 pension rewards equation have the 'wrong' sign. Strictly speaking, only three of eight coefficients are directly supportive of the theory.

Other variables informative on the regulation hypothesis are the time effects, specified as year-specific intercepts for 1970 and 1980 (as compared to 1960). The estimated coefficients are only suggestive as to whether mandatory retirement and other regulation affected pension incentives, since unmeasured factors could certainly have played a role as well. On the other hand the fact that industry and labor market controls are included in all models should increase the chance that the time effects actually do reveal the impact of changes in the regulatory environment. The empirical evidence reveals that benefit levels rose in real terms from the 1960's through the 1980's. Also, the incentives for retiring early versus late were strengthened over time and the peak pension age fell. In addition, all estimated magnitudes but one (for PSLOPE65-62) are quantitatively larger in 1980 than in 1970 . Since most pension reforms were enacted after 1970 , this 
evidence does not contradict the conclusion that changes in regulation induced pension plans to reward earlier retirement over time.

The third hypothesis, pertaining to the effects of monitoring, specified that larger firms or those with a higher proportion of production workers might make use of early retirement incentive to reduce the need for monitoring older workers. The evidence here is largely inconsistent with this view. Greater firm size and larger fractions of production workers (FSIZE and PRODTOT) are not significantly associated with peak pension age; and contrary to hypothesis are apparently related to lower pension benefit levels and higher rewards for post- 65 retirement. In only one case is the evidence compatible with the theory: firms with few supervisors offer lower rewards for deferring retirement after age 62 . In gerieral, the monitoring hypothesis does not seem to adequately explain the significant roles that firm size and employment mix play in pension structures. 17

One additional control variable is included in all models, which is a multiemployer intercept term. Such pension plans appear to differ substantively from other plans in terms of their retirement incentives: 18 they build in higher peak pension ages, and of fer lower benefit levels for retirement at both ages 62 and 65 . In addition, the PSLOPE equations indicate that delayed retirement is generally rewarded financially among these pension plans. In general, then, multiemployer plans rewarded continued work more than do single-employer pension plans. One possible interpretation of this finding is that multiemployer plans were and are more prevalent in sectors where workers internalize their own productivity. This could be true where output is easily counted (e.g. piecework in the garment industry, or in trucking) or where work effort can be closely monitored (e.g. in construction). In such cases employers might have less need to use their

\footnotetext{
${ }^{17}$ Similar results on these variables were obtained when firm-level data were used on a subsample of sponsoring firms for whom Compustat data were available. Hence we conclude that the use of industry-level data cannot explain observed patterns for these variables.
}

18 Mitchell and Andrews (1981) note other differences between single and multiemployer pension plans. 
pension plans to effect early retirement for workers whose declining productivity might go unnoticed in other industries. More analysis of this point is offered below

Table 4 presents estimates of changes in peak pension age which could be expected from a ten percent change in given explanatory variables. The largest expected change is due to average workforce tenure: were this to rise by ten percent ( 2 years, in our sample), PKPAGE would fall by 16 years. The next largest change would be induced by a change in firm profitability: if ROI5 rose by ten percent, PKPAGE would increase by .11 years. The only other substantive finding is a .06 year rise in PKPAGE following from a 10\% increase in PDVSS62. In general these responses seem quantitatively very small.

\section{Results: Multiemployer Subsample}

Policymakers have recently expressed strong interest in enhanced pension portability, in part because they believe that this would increase retirement income security for today's mobile workforce (Walker, 1988). Because multiemployer plans permit more portability than other plans, and because multiemployer plans appear distinct from other plans observed in our sample in some respects, separate analysis of the subsample of multiemployer plans is warranted. Table 5 tabulates pension mean values for multiemployer plans, while Table 6 summarizes multivariate regression results.

The most important finding is that muldemployer pension plans reward deferred retirement more than do other pensions. Comparing Table 5 to Table l, multis offer lower pension benefit levels and impose lesser penalties for workers to remain employed into their 60's. Further, these pattems grew stronger over time. In 1960 the multiemployers had slightly lower peak retirement ages than the rest of the sample, but by the 1980's their peak pension age was higher than the fullsample average. Multivariate analysis confirms these conclusions, even after controlling on other factors which might distinguish them from their single-employer counterparts. 19 Among multiemployer plans, growing industries had higher benefit levels and penalties for delayed

19 In all cases, F-tests reject (at the $5 \%$ level or better) the hypothesis that all interactions of explanatory variables with a multiemployer effect are equal to zero in each of the equations. See Table 6 as compared to Table 3. 
retirement, as compared to single employer plans. Also in the multis, longer term employees and to some extent the highly-paid were particularly likely to be encouraged to remain on the job at later ages as compared to the singles. So the evidence suggests that for this sample during the period under study, multiemployer plans moved toward rewarding longer work while many singleemployer plans took the opposite tack, offering greater incentives toward earlier retirement.

\section{Conclusions}

At the outset we noted that some believe the US labor market will fail to adapt smoothly to an aging workforce, whereas others contend that pensions can and will play an important rule in helping companies induce desired turnover patterns. The present research suggests several important conclusions along these lines. First, the plans under study instituted many changes between 1960 and 1980 , several of which enhanced the financial payoff to early retirement. These changes included increases in benefit levels, reductions in early, normal and mandatory retirement ages, and cuts in the age at which pension present values peaked (with retirement after that age being penalized).

A second conclusion pertains to the empirical relationship between pension provision variables and pension value variables, which has previously only been guessed at by pension analysts: it is quite weak. This suggests that simple indicators of pension plans' structural features (e.g. the plan's early retirement age) do not adequately summarize the complex financial incentives inherent in pensions influences on workers' retirement decisions.

A third conclusion has to do with explanations for the observed pension dynamics. There is some evidence supporting the buy-out hypothesis: that is, workers with high tenure were probably encouraged to retire earlier, thus allowing firms to hire new (and presumably less expensive) employees. This evidence portends that changes in the demographic composition of the labor force may imply future changes in pension retirement incentives. The implications of the buy-out hypothesis with respect to product market dimensions received weaker support, but less well-off firms do appear to use pension incentives to buy out older workers. 
There is additional information regarding two other hypotheses of policy interest. The regulatory environment in which pensions operate was found to have an important impact on employer-sponsored pension retirement incentives, particularly with regard to Social Security rule changes. Less direct evidence was available on changes in mandatory retirement rules and other regulatory changes (e.g. ERISA and subsequent regulation) but there is some support for the view that employers altered pensions so as to offset the legal raising of the mandatory retirement age.

Last but not least, multi-employer plans were found to have evolved in ways that were significantly different from the changes in single employer plans. Specifically, multi-employer plans in this sample were more likely to encourage continued employment at older ages. If government efforts to enhance portability take the forn of encouraging multiemployer plans, this may also achieve another federal government policy cbjective -- namely, delayed retirement.

This research contributes to knowledge by focusing on the largest set of pension plans ever followed for such a long time period. On the other hand we recognize that it remains a small sample, and a collectively bargained sample at that. Nevertheless, with these caveats, it is safe to conclude that retirement incentives inherent in employer-sponsored pensions can and Jo change dramatically over time. Further, pension plan behavior is systematicaliy related to labor force characteristics, firm profitability, and labor market regulation. Our results suggest that government as well as corporate retirement policy must take into consideration this dynamic nature of pension plans. 


\section{Table 1. \\ Means of Pensien Provision and \\ Pension Value Variables \\ (\$1970)}

\begin{tabular}{cccc} 
Three Decade & \multicolumn{3}{c}{ Pension Plan Observed in: } \\
Average & 1960 & 1970 & 1980 \\
\hline
\end{tabular}

Pension Provisions:

$\begin{array}{lrrrr}\text { LYAGE } & 57.74 & 58.55 & 57.00 & 57.76 \\ \text { LYSUPP (\%) } & .12 & .03 & .17 & .15 \\ \text { LYSV (years) } & 12.50 & 12.97 & 12.75 & 11.82 \\ \text { NAGE } & 63.60 & 63.78 & 63.68 & 63.33 \\ \text { NSV (years) } & 11.33 & 10.70 & 12.36 & 10.84 \\ \text { MANRET }(\%) & .56 & .50 & .58 & .59 \\ \text { MRAGE } & 68.79 & 69.11 & 68.68 & 68.59 \\ \text { SCANRA }(\%) & .73 & .68 & .76 & .75\end{array}$

Pension Values:

PKPAGE (years)

PDVP62 (\$)

PDVP65 (\$)

PSLOPE65-62 (\$)

PSLOPE67-65 (\$)
63.09

11544

12858

1314

$-6271$
63.87

4586

6742

2155

$-3467$
62.82

14344

15445

1101

.7820
62.65

15166

15907

741

.7284

Variable Definitions:

LYAGE: Early retinement age.

LYSUPP: Indicator variable identifying whether an early retirement supplement was provided.

LYSV: Years of service required for early retirement.

NAGE: Nomal retirement age.

NSV: Years of service required for nomal retirement.

MANRET: Indicator variable identifying whether mandatory retirement in effect.

MRAGE: Age of Mandatory Retirement.

SCANRA: Indicator variable identifying whether service credited after normal retirement age.

PKPAGE: The age at which the present discounted value of pension benefits attains a maximum (age range 60-67 inclusive).

PDVP62: Dollars of present discounted value of pension benefits if worker retired at age 62.

PDVP65: Same as PDVP62 but defined for age 65.

PSLOPE65-62: PDVP65-PDVP62.

PSLOPE67-65: PDVP67-PDVP65.

Other variable defintions are given in Table $\mathrm{l}$. 


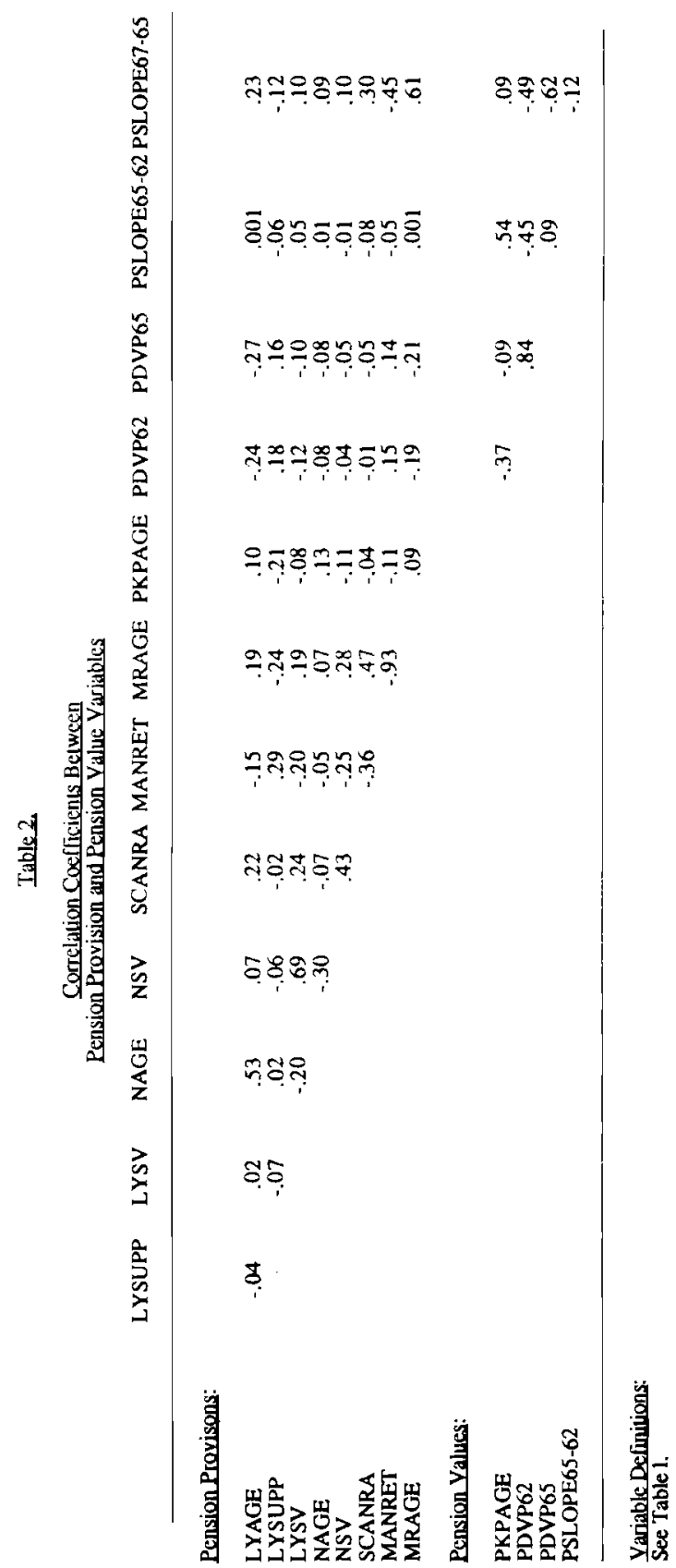


Table 3.

Deteminants of Petrion Retirement Incentives

(Standard errors in parentheses)

\begin{tabular}{|c|c|c|c|c|}
\hline \multicolumn{5}{|c|}{ Dependent Variables: } \\
\hline PKPAGEa & PDVP62 & PDVP65 & PSLOPE65-62 & PSLOPE67-65 \\
\hline
\end{tabular}

Explanatory Variables:

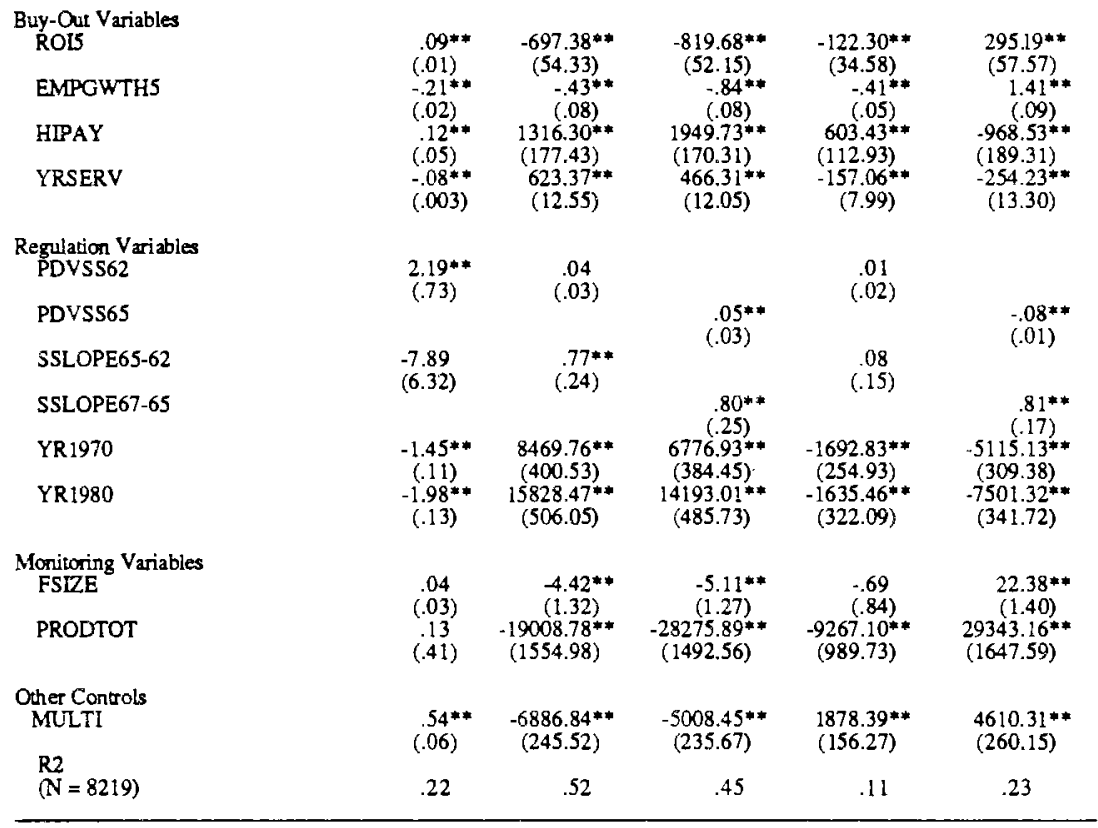

Notes:

$+t_{\mathrm{t}} \geq 1.96$

$* \geq 1.65(<1.96)$

afl the PKPAGE equation, coefficients on Social Security and time variables have been multipled by 105 , the coefficient on FSIZE has been multiplied by 102, and the coefficient on EMPGWTHS has been multiplied by 103.

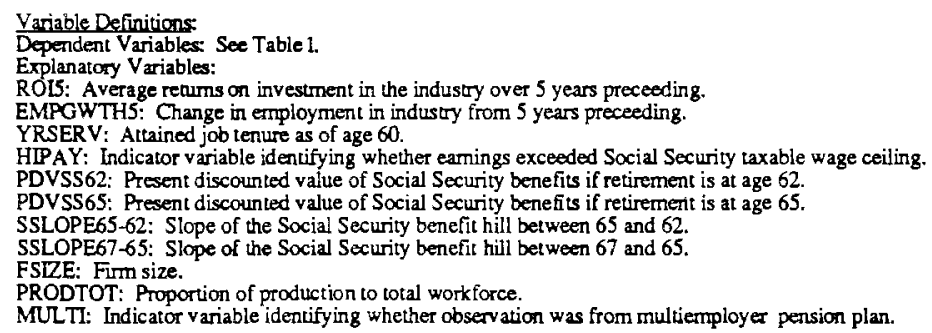


Table 4.

Expected Change in PKPAGE Given a

Ten Percent Change in Explanatory Variable

Ten Percent Change In

Buy-Out Variables

\section{ROI5}

EMPGWTH5

HIPAY

YRSERV

Regulation Variables

PDVSS62

SSLOPE65-62

Monitoring Variables

FSIZE

PRODTOT

Other Controls

MULTI

\section{Expected Change in PKPAGE}

.11

$-.02$

.01

$-.16$

.06

NS

NS

NS

.02

\section{Notes:}

Calculations based on Table 3 coefficients and Appendix 3 means.

$\mathrm{NS}=$ coefficient not statistically significant at .05 level. 
Table 5 .

Means of Dependent Variables by Year for Multiemployer Subsample

\begin{tabular}{llll}
\hline & \multicolumn{3}{c}{ Pension Plan Observed in: } \\
$\begin{array}{c}\text { Three Decade } \\
\text { Average }\end{array}$ & 1960 & 1970 & 1980 \\
\hline
\end{tabular}

\section{Pension Provisions:}

\section{LYAGE \\ LYSUPP (\%) \\ LYSV (years) \\ NAGE \\ NSV (years) \\ MANRET (\%) \\ MRAGE \\ SCANRA (\%)}

Pension Values:

PKPAGE (yrs)

PDVP62 (\$)

PDVP65 (\$)

PSLOPE65-62 (\$)

PSLOPE67-65 (\$)
59.3

.02

14.8

63.6

15.0

.2

71.3

.95
60.8

.0

16.0

62.7

16.0

71.1

.96

57.3
.1
15.7
63.7
16.8
.2.
71.1
.96

60.0

.0

12.7

64.3

12.1

.3

71.3

.90

\section{Variable Definitions:}

See Table 1.

$\begin{array}{rrrr}63.2 & 63.5 & 63.1 & 63.1 \\ 8544 & 2848 & 11533 & 10421 \\ 10106 & 5433 & 12652 & 11547 \\ 1562 & 2586 & 1119 & 1126 \\ -2572 & -1204 & -3786 & -2511\end{array}$


Table 6

Determinants of Multiemployer Pension Retirement Incentives (Standard errors in parentheses)

Dependent Variables:

PKPAGE1 PDVP62 PDVP65 PSLOPE65-62 PSLOPE67-65

Explanatory Variables:

Buy-Out Variables ROI5

EMPGWTH5

HIPAY

YRSERV

$\begin{array}{lcccc}.06^{* *} & -590.07^{* *} & -711.25^{* *} & -121.18^{* *} & 199.85^{* *} \\ (.02) & (61.49) & (59.27) & (39.84) & (65.61) \\ -.20^{* *} & -.66^{* *} & -1.04^{* *} & -.38^{* *} & 1.811^{* *} \\ (.02) & (.09) & (.08) & (.06) & (.09) \\ .16^{* *} & 1651.03^{* *} & 2387.06^{* *} & 736.03^{* *} & -1222.16^{* *} \\ (.05) & (194.74) & (187.72) & (126.18) & (208.72) \\ -.10^{* *} & 701.61 * * & 508.61 * * & -193.00^{* *} & -196.45^{* *} \\ (.004) & (13.74) & (13.24) & (8.90) & (14.66)\end{array}$

Regulation Variables PDVSS62

$2.74^{* *} \quad .05$

PDVSS65

SSLOPE65-62

$-9.97$

(7.03)

(.03)

.02

$(.02)$

$.06 * *$

$-.11^{* *}$

(.01)

SSLOPE67-65

$(.00 *$

.11

(.17)

YRI970

$-1.54^{* *}$

(.12)

$-2.15^{* *}$

(.14)

(.03)

$1.05^{* *}$

(.28)

YR1980

8906.72** (442.59) $16932.72 * *$

$7095.01^{* *}$ (426.63)

(542.18)

$15357.18 * *$
$(522.63)$

$-1811.71^{*}$

(286.77)

$-1575.54 * *$

$(351,29)$

$1.06^{* *}$
$(.19)$
$-6108.79^{* *}$
$(339.42)$
$-8540.76^{* *}$
$(356.96)$

Monitoring Variables

FSIZE

PRODTOT

$\begin{array}{ccccc}-.02 & -3.88^{* *} & -4.27^{* *} & -.40 & 25.79 * * \\ (.04) & (1.34) & (1.29) & (.87) & (1.43) \\ -1.29^{* *} & -18995.95^{* *} & -27176.54^{* *} & -8180.59 * * & 35189.62^{* *} \\ (.48) & (1796.36) & (1731.58) & (1163.91) & (1916.73)\end{array}$

Other Controls

MULTI

$\begin{array}{lcccc}-4.74 * * & 1448.63 & -462.67 & -1911.30 & 19435.49^{* *} \\ (1.15) & (4314.75) & (4159.17) & (2795.66) & (4694.55)\end{array}$

-continued- 
Dependent Variables:

$\begin{array}{llll}\text { PKPAGEal PDVP62 PDVP65 PSLOPE65-62 PSLOPE67-65 } & \text { P }\end{array}$

Interaction Terms

Buy-Out Variables MROI5

MEMPGWTH5

MIIPAY

MYRSERV

Regulation Variables MPDVSS62

MPDVSS65

MSSlope65-62

MSSlope67-65

MYR70

MYR80

Monitoring Variables

MFSIZE

MPRODTOT

$(\mathrm{N}=8219)$

$\begin{array}{lc}.01 & -195.25 \\ (.06) & (221.66) \\ .01 & 1.42^{* *} \\ (.07) & (.25) \\ .15 & -1585.04^{* *} \\ (.11) & (426.89) \\ .08^{* *} & -382.80^{* *} \\ (.01) & (30.39)\end{array}$

229.94
$(213.67)$
$1.03^{* *}$
$(.24)$
$-2246.00^{* *}$
$(411.49)$
$-206.94^{* *}$
$(29.29)$

425.19**

(143.62)

$-.39 * *$

(.16)

$-660.96^{* *}$

(276.59)

$175.85^{* *}$

(19.69)

$-30.30$

(236.52)

$-2.69 * *$

(.27)

$1256.10^{* *}$

(461.67)

$206.57^{* *}$

(32.42)

\begin{tabular}{|c|c|c|c|c|}
\hline \multirow[t]{2}{*}{$\begin{array}{l}-3.22 * \\
(1.85)\end{array}$} & \multirow[t]{2}{*}{$\begin{array}{l}-.07 \\
(.07)\end{array}$} & \multicolumn{3}{|c|}{$\begin{array}{l}. .01 \\
(.04)\end{array}$} \\
\hline & & $\begin{array}{l}. .08 \\
(.07)\end{array}$ & & $\frac{.11^{* *}}{(.03)}$ \\
\hline $\begin{array}{c}14.94 \\
(15.42)\end{array}$ & $\begin{array}{l}-.67 \\
(.58)\end{array}$ & & $\begin{array}{l}-.07 \\
(.38)\end{array}$ & \\
\hline & & $\begin{array}{l}-.66 \\
(.62)\end{array}$ & & $\begin{array}{c}-1.06^{* *} \\
(.40)\end{array}$ \\
\hline $\begin{array}{l}.44 \\
(.32) \\
1.41^{* *} \\
(.49)\end{array}$ & $\begin{array}{l}-1386.39 \\
(1218.35) \\
-3480.90^{\star} \\
(1830.08)\end{array}$ & $\begin{array}{l}-2649.83^{* *} \\
(1174.42) \\
-6812.15^{* *} \\
(1764.09)\end{array}$ & $\begin{array}{c}-1263.43 \\
(789.41) \\
-3331.25^{* *} \\
(1185.76)\end{array}$ & $\begin{array}{c}4504.03^{* *} \\
(1115.14) \\
6349.90^{* *} \\
(1665.45)\end{array}$ \\
\hline
\end{tabular}

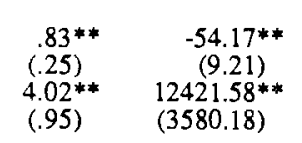
$-37.25 * *$
(8.87)
8612.97 **
16.92 **
(5.97)
(3451.09)
$-3808.61$
(2319.71)

$-13.81$

(9.82)

$-32707.74^{* *}$

(3820.09)

$.24 \quad .54$

.47

.13

.26

\section{Notes:}

$* *_{t} \geq 1.96$

$* \geq 1.65$ (<1.96)

afth the PKPAGE equation, coefficients on Social Security and time variables have been multiplied by 105 , the coefficient on FSIZE has been multiplied by 102 , and the coefficient on EMPGWTH5 has been multiplied by $1 \mathrm{C}$

Variable Defunitions:

See Table l. All interaction terms are original variables multiplied by MULTI. 


\section{APPENDIX I}

\section{Pension Plans Included in Analysis}

Firm or Industry
Addressograph

Alabama Power

Alcos

AMBAS (America Bosch

American Can

American Standard

Anaconda Amer Brass

Armour

Armstrong Cork

Bendix

Boeing

Bronx Realty Adv Bd

Campbell Soup

\section{Caterpillar}

Chicago Transit

Clothing Ind.

Coal Ind.

Construction (NY)

Construction (NECA)

Construction (NYECA)

Construction (SF)

Construction (Chicago)

Continental Can

Detroit Edison

Detroit Tooling Asso

Doll Manufacturers (NY)

Dravo

Elrra

Firestone

Food Ind.

Ford

Fur Mfg Ind.

Garment (cotton) Ind.

Garment (womens, children) Ind.

\section{General Foods}

\section{GM}

General Telephone

Handbag (ladies) Ind.

Honeywell

Hospitals of SF

Hospitals, and Retail

Drug Ind.

Hotel Assoc of NYC
Union

Years Included

OPEIU
IAM

IBEW

Aluminum Wkrs

USWA

IUE

USWA

Std. Allied

Trades Council

USWA

Meat Cutters

Rubber Workers

UAW, IAM

IAM

SEIU

Meat Cut:ers

UPWA

UAW

ATU

ACTW

UMW

Carpenters

IBEW

IBEW

Plumbers

Plumbers

Paperworkers

IBEW

UAW

Toymakers

Shipbuilders

UAW

Rubber Workers

Retail Clerks

UAW

Meat Cutters

ACTW

$60,70,80$

$60,70,80$

$60,70,80$

$60,70,80$

$60,70,80$

$60,70,80$

60,70

$60,70,80$

$60,70,80$

$60,70,80$

$60,70,80$

$60,70,80$

$60,70,80$

$60,70,80$

$60,70,80$

$60,70,80$

$60,70,80$

$60,70,80$

$60,70,80$

$60,70,80$

$60,70,80$

$60,70,80$

$60,70,80$

$60,70,80$

70,80

70,80

$60,70,80$

$60,70,80$

$60,70,80$

$60,70,80$

60,70

$60,70,80$

$60,70,80$

ILGWU

various unions

UAW

CWA

Pocketbook Wkrs

Teamsters

ANA, SEIU

$60,70,80$

$60,70,80$

$60,70,80$

$60,70,80$

$60,70,80$

70,80

70,80

RWDSU

$60,70,80$

Hotel Workers

$60,70,80$ 


\begin{tabular}{|c|c|c|c|}
\hline 43 & Intemat'! Harvester & UAW & $60,70,80$ \\
\hline 44 & Intemat'l Paper & Paperworkers & $60,70,80$ \\
\hline 45 & John Hancock & Insurance Whrs & $60,70,80$ \\
\hline 46 & Kennecot & USWA & $60,70,80$ \\
\hline 47 & Keystone & UAW & 70,80 \\
\hline 48 & Laundry Ind. & $\mathrm{ACTW}$ & 70,80 \\
\hline 49 & Lever Bros. & $\begin{array}{l}\text { Chemical Wkrs } \\
\text { OCAW }\end{array}$ & $60,70,80$ \\
\hline 50 & Lumber Ind. (So.Cal) & Carpenters & $60,70,80$ \\
\hline 51 & Maritime Ind. & Maritime Union & $60,70,80$ \\
\hline 52 & Maritime Ind. & $\begin{array}{l}\text { Masters, Mates } \\
\text { and Pilots }\end{array}$ & $60,70,80$ \\
\hline 53 & McDonald Douglas & UAW & $60,70,80$ \\
\hline 54 & Melville Shoe & NH Shoe Wkrs & $60,70,80$ \\
\hline 55 & Metalworking Ind. & IAM & $60,70,80$ \\
\hline 56 & Milk Dealers & Teamsters & $60,70,80$ \\
\hline 57 & Monsanto & Chemical Wkrs & $60,70,80$ \\
\hline 58 & NYShipping Asso. & Longshoremen & $60,70,80$ \\
\hline 59 & New York Times & Newspaper Guild & $60,70,80$ \\
\hline 60 & Owens Dlinois & Glass Blowers & $60,70,80$ \\
\hline 61 & Pacific Gas \& Elec. & IBEW & $60,70,80$ \\
\hline 62 & Pacific Maritime Asso. & Longshoremen & $60,70,80$ \\
\hline 63 & Painters \& Decorators & Painters & $60,70,80$ \\
\hline 64 & Pittsburg Plate Glass & Glass Workers & $60,70,80$ \\
\hline 65 & Pullman & USWA & $60,70,80$ \\
\hline 66 & Restaurant Ind. (NYC) & Restacrant Wkrs & $60,70,80$ \\
\hline 67 & Reynolds & USWA & $60,70,80$ \\
\hline 68 & Rheem & USWA & 60,70 \\
\hline 69 & Scoville Mfg & UAW & $60,70,80$ \\
\hline 70 & Shipyard Ind. (Pacific) & Metal Trades & 70,80 \\
\hline 71 & SEPTA & TWU & 70,80 \\
\hline 72 & Sperry Rand & IUE & $60,70,80$ \\
\hline 73 & Textile Ind. & Textile Wkrs & $60,70,80$ \\
\hline 74 & $\begin{array}{l}\text { Trucking Ind. } \\
\text { (Central States }\end{array}$ & Teamsters & $60,70,80$ \\
\hline 75 & Union Carbide & $\begin{array}{l}\text { Atomic Trades } \\
\text { \& Labor Council }\end{array}$ & $60,70,80$ \\
\hline 76 & Uniroyal & Rubber Workers & 60,70 \\
\hline 77 & United Airlines & IAM & 70,80 \\
\hline 78 & US Steel & USWA & $60,70,80$ \\
\hline 79 & Upholstering Ind. & Upholsterers & $60,70,80$ \\
\hline 80 & Westem Union & Telegraph Wkrs & $60,70,80$ \\
\hline 81 & Westinghouse & IUE & $60,70,80$ \\
\hline 82 & Westvaco & Paperworkers & $60,70,80$ \\
\hline 83 & Weyerhauser & Woodworkers & 60,70 \\
\hline
\end{tabular}

Notes:

Union abbreviations on next page.

Source: US Department of Labor. Digest of One Hundred Selected Pension Plans Under Collective Bargaining, USGPO (various years). 
Key to Union Abbreviations

ACTW
ANA
ATU
Camenters
Chemical Wkrs
CWA
Glass Blowers
Glass Workers
Hotel Workers
IAM
IBEW
ILGWU
Insurance Wkrs
IUE

Longshoremen

Maritime Union Mear Cutters

Newspaper Guild

OCAW

OPEIU

Painters

Paperworkers

Pocketbook Wkrs

Plumbers

Restaurant Wkrs

Retail Clerks

Rubber Workers

RWDSU

SEIU

Shipbuilders

Teamsters

Telegraph Wkrs

Textile Workers

Toymakers

TWU

UAW

UMW

Upholsterers

UPWA

USWA

Woodworkers
Amalgamated Clothing and Textile Workers of America

American Nurses Association

Amalgamated Transit Union

United Brotherhood of Carpenters and Joiners of America

International Chemical Workers Union

Communication Workers of America

Glass Bottle Blowers Association of the U.S. \& Canada

United Glass and Ceramic Workers of North America

NY Hotel and Motel Trades Council

International Association of Machinists

International Brotherhood of Electrical Workers

International Ladies' Garment Workers Union

Insurance Workers Intemational Union

Intemational Union of Electrical, Radio, and

Machine Workers

International Longshoremen's Associarion

National Maritime Union of America

Amalgamated Meat Cutters and Butcher Workmen of North America

American Newspaper Guild

Oil, Chemical and Atomic Workers Intemational

Office and Professional Employees Intemational Union

Intemational Brotherhood of Painters and Allied Trades

United Paperworkers Intemational Union

International Leather Goods, Plastic and Novelty

Workers Union

United Association of Joumeymen and Apprentices of the Plumbing and

Pipe Fitting Industry

Hotel and Restaurant Employees and Bartenders Intemational

Retail Clerks Intemational Association

United Rubber Workers

Retail, Wholesale and Department Store Union

Service Employees Intemational Union

Industrial Union of Marine and Shipbuilding Workers of America

Intemational Brotherhood of Teamsters, Chauffeurs,

Warehousemen and Helpers of America

United Telegraph Workers

Textile Workers Union of America

International Union of Dolls, Toys, Playthings,

Novelties and Allied Products of the US and Canada

Transpor Workers Union of America

United Automobile, Aerospace and Agricultural Implement

Workers of America

United Mine Workers of America

Upholsterers International Union of North America

United Packinghouse Workers of America

United Steelworkers of America

International Woodworkers of America 


\section{APPENDIX II}

\section{Description of Data Sources}

\section{Source of Pension Benefit Values:}

Pension benefits are computed for sixty illustrative workers obtained by specifying five different eamings levels, six tenure levels, and workers in two marital status groups (single and married). The eamings profiles examined include an average eamings profile reflecting actual pay of older workers covered by pensions taken from the Longitudinal Retrement History Survey and two additional profiles at $20 \%$ above and below this average level. LRHS earnings streams are moved back to the 1960 's and forward to the 1980's using the inflation rate. This approach holds constant real earnings across the decades so as to better compare resultant benefit patterns. In addition a low-wage profile (a minimum-wage worker) and high-wage profile (someone at the Social Security taxable maximum) are examined. Tenure profiles are assumed to vary according to the number of years of service accumulated as of age 60 ; ten, twenty and thinty years are used, as well as fifteen, twenty-two, and twenty-five representing low, mean and high years of seniority found in earlier research (Fields and Mitchell, 1984).

Annual perision amounts are computed by evaluating expected benefits for each of the plans described in the series of Bureau of Labor Statistics publications entitled "Digest of One Hundred Selected Pension Plans Under Collective Bargaining" (US Department of Labor, various issues). These amounts are then converted to present values using a $2 \%$ real discount rate, as well as survival probabilities based on life tables specific to workers reaching age 60 in each of the three decades (see Mitchell and Luzadis 1988).

\section{Source of Social Security Benefit Variables:}

Social Security benefit and present values were constructed by evaluating for each worker in the sample the benefits he would receive if he retired at the specified age. Because Social Security regulations changed over time we employ the rules in effect at the time the worker turned age 60 (in 1960,1970 and 1980, respectively). Net present values of real Social Security benefits at age 60 assume retirement at age 60 followed by filing at age 62 when the retiree is first eligible. Other present values are defined assuming that the worker retired at that age and immediately applied for Social Security. Present value computations assume a real discount rate of $2 \%$ real and mortality figures applying to the cohort in question. In all cases social security present values are computed assuming that nominal benefits are inflated at the same rate as had prevailed in the decade prior to the worker attaining age 60 (For a justification see Fields and Mitchell, 1984; and Mitchell and Luzadis, 1988). 
Sources of Other Explanatory Variables:

EMPGWTH5: Growth in number of employees over last five years (Source: Bureau of the Census, County Business Patterns).

ROI5: 5-year (quarterly average) rate of return on investment (Source: Bureau of the Census, Quarterly Financial Report for Manufacturing Corporations - 4Qeds.).

YRSERV: Years of service at age 60 (Source: by construction).

HIPAY: Equal to 1 if earnings at Social Security taxable maximum in all years, 0 else (Source: by construction).

YR1970: Time effect equal to one if observation from 1970, 0 else.

YR1980: Time effect equal to one if observation from 1980, 0 else.

FSIZE: Number of employees per firm (Source: Bureau of the Census, County Business Patterns).

PRODTOT: Fraction of production workers to all employees (Source: Bureau of Labor Statistics, Employment, Hours and Earnings).

MULTI: Equal to 1 if observation was a multiemployer plan, 0 else (Source: "Digest of One Hundred Selected Pension Plans Under Collective Bargaining", US Department of Labor, various issues). 
APPENDIX III

Means of Explanatory Variables

\begin{tabular}{cccc}
\hline & \multicolumn{3}{c}{ Pension Plan Observed in: } \\
$\begin{array}{c}\text { Three Decade } \\
\text { Average }\end{array}$ & 1960 & 1970 & 1980 \\
\hline
\end{tabular}

Buv-Out Variables:

ROIS (pct. pts.)
EMPGWTH5 (\#)
YRSERV (years)

HIPAY (\%)

11.67
834.19
20.33
.40

9.95

$-125.97$

20.33

.40

11.45

966.80

13.87

.40

20.33

.40

20.33

.40

Regulation Variables:

$\begin{array}{lrrrr}\text { PDVSS62 (\$) } & 29486 & 24099 & 35857 & 27857 \\ \text { PDVSS65 (\$) } & 31887 & 26077 & 40: 97 & 28535 \\ \text { SSLOPE65-62(\$) } & 2401 & 1977 & 4440 & 678 \\ \text { SSLOPE67-65(\$) } & -2033 & -2524 & -1819 & -1799\end{array}$

Monitoring Variables:

FSIZE (\#)

PRODTOT (\%)

76.21

78.18

77.52

72.99

.76

.78

.76

.74

Qther Variables:

MULTI (\%)

.38

.36

.39

.40

Variable Definitions:

See Tables 1 and 3. 


\section{References}

Allen, S. G., R. L. Clark, and D. A. Sumner. "Postretirement Adjustments of Pension Benefits". Joumal of Human Resources 21, Winter 1986.

Bell, D. and W. Barclay. "Trends in Retirement Eligibility and Pension Benefits, 1974-83." Monthly Labor Review 110, April 1987: 18-25.

Burkhauser, R. V. "The Pension Acceptance Decision of Older Workers." Joumal of Human Resources 14, Winter 1979: 63-75.

Clark, R. L., S. F. Gohmann, and A. A. McDermed. "Declining Use of Defined Benefit Pension Plans: Is Federal Regulation the Reason?" Working Paper No. 119. April 1988.

Fields, G. S. and O. S. Mitchell. Retirement, Pensions and Social Security. Cambridge: MIT Press, 1984.

Gustman, A. L. and T. L. Steinmeier. "An Analysis of Pension Benefit Formulas, Pension Wealth, and Incentives From Pensions." In R. Ehrenberg, ed. Research in Labor Ecenomics, forthcoming 1989.

Hutchens, R. "Delayed Payment Contracts and a Firm's Propensity to Hire Older Workers." Loumal of Laber Economics 4, October 1986: 439-457.

Ippolito, R. "Towards Explaining Earlier Retirement After 1970." Paper delivered at the New York AEA Meetings, December 1988.

Kotlikoff, L. and D. E. Smith. Pensions and the American Economy. Chicago: University of Chicago Press, 1983.

Lazear, E. "Pensions as Severance Pay". In Z. Bodie and J. Shoven, eds. Einancial Aspects of the United States Pension System. NBER. Chicago: University of Chicago Press, 1983.

Lazear, E. "Why Is There Mandatory Retirement?" Loumal of Political Economy 87, 1979: 1261 1284.

Levine, P. B. and O. S. Mitchell. "The Baby Boom's Legacy: Relative Wages in the 21st Century." American Economic Review 78, May 1988: 66-69. 
Mitchell, O.S. and E. Andrews. "Scale Economics in Private Multi-Employer Pension Systems". Induscrial and Labor Relations Review 34, July 1981: 522-530.

Mitchell, O. S. and R, A. Luzadis. "Changes in Pension Incentives Through Time." Industrial and Labor Relations Review 42, October 1988: 100-108.

Mutschler, P.H. and J.H. Schulz. "Factors in the Retirement Decision". Brandeis University, mimeo. January 1987.

Russell, L. B. The Baby Boom Generation and the Economy. Brookings Institution, Washington, DC. 1982.

Social Security Administration. Social Security Bulletin. Annual Statistical Supplement. USGPO, December 1986.

Stock, J. H. and D. A. Wise. "Pensions, The Option Value of Work, and Retirement." NBER Working Paper No. 2686. August 1988.

U.S. Bureau of the Census. County Business Pattems. Washington, D.C.: U.S. Government Printing Office, various years.

U.S. Bureau of the Census. Quarterly Financial Report for Manufacturing Corporations, 4th quarter editions. Washington, D.C.: U.S. Govemment Printing Office, various years.

U.S. Bureau of Labor Statistics. Digest of One Hundred Selected Pension Plans Under Collective Bargaining. Washington, D.C.: U.S. Govemment Printing Office, various years.

U.S. Bureau of Labor Statistics. Employment. Hours and Eamings. Washington, D.C.: U.S. Govemment Printing Office, various years.

Walker, D. M. "Statement on Pension Portability" before House Ways and Means Oversight Subcommittee, July 12, 1988. 